\title{
Sexual Harassment At Work Place: A Study Of Women Political Workers In Pakistan
}

\author{
Aliyah Ali \\ \& \\ Rukhsana \\ Women's Studies \\ University of Karachi
}

\begin{abstract}
Sexual harassment in the work place including political sphere is widespread in Pakistan but actual number of cases are not available, issue is still under the carpet. This unwanted and annoying sex-related behaviour and concealing phenomena is the part of all professions. The present study explored the contemporary status of harassment in Pakistani women political workers. For this exploratory research the data has collected from 200 women political workers through survey method with purposive and snow ball sampling procedures. The quantitative data has collected in different areas of Karachi. Findings of the study revealed that all respondents women have faced verbal and non-verbal harassment during election, demonstrations and their workplace as well. The results of the research shows that empowered women have no courage to report this heinous crime due to social pressure or fear because they do not want to destroy their chastity. In Pakistan, female participation in all professions including political sphere is increasing constantly and immediate need to address the issue of harassment at world of work.
\end{abstract}

Keywords: Women Political Workers, Sexual Harassment, Sexual Violence, Verbal and Non-Verbal Violence.

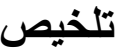

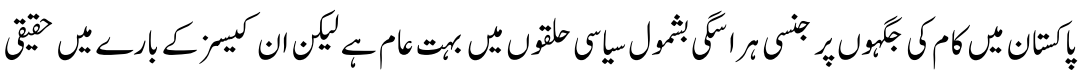

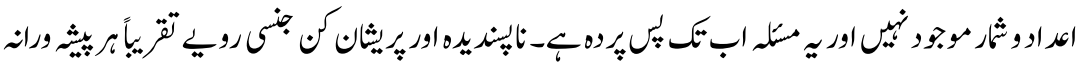

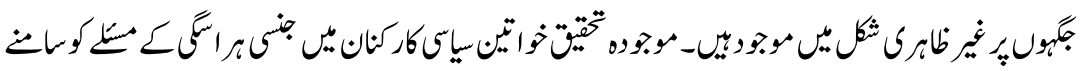

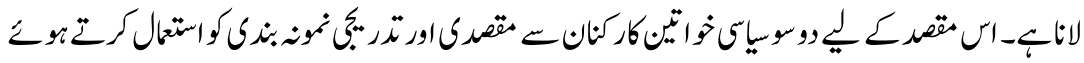

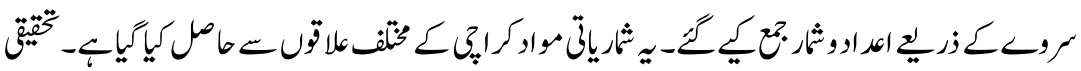

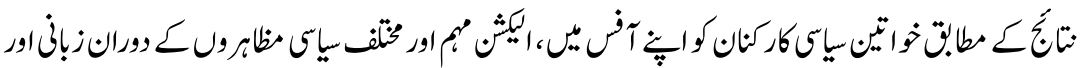

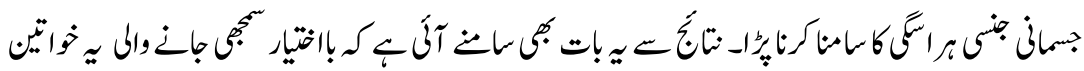

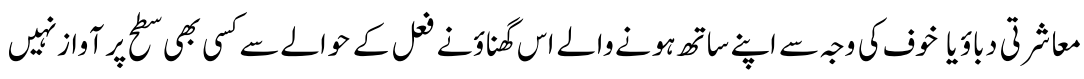




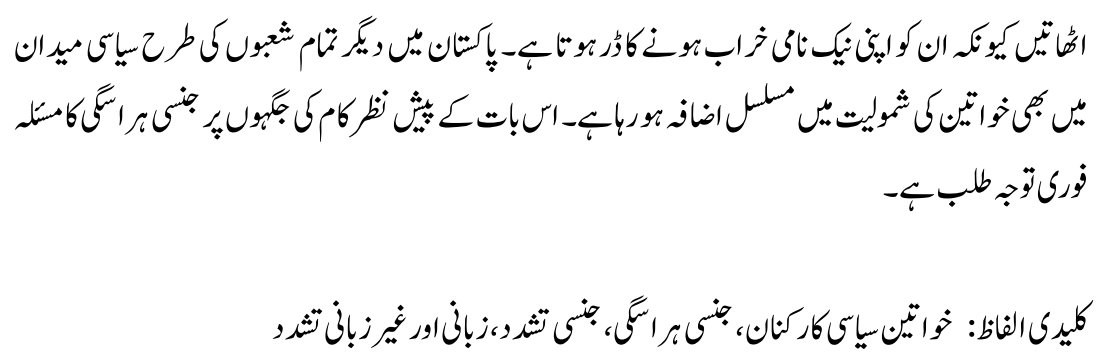

\section{Introduction}

Women's problems and worries seem to be never stopped in almost every part of the world. In this existing scenario, women participation increased in every field of work and human society is able to be pleased the existence of a rules and regulations about sexual abused and harassment at the place of work in strength, the exposure of females to this unacceptable crime has spread multifarious problem, which are preventing women to work (Sadruddin, 2013).

Sexual harassment is an acute form of gender discrimination and continuing delinquent issue for women (ILO, 2018). When women come out of the dwelling to seek employment she is subjected to have unwanted sexual attention in the form of lustful hints, verbal or physical indications and even request for sexual favours (HRPA, 2018). It is annoying carnal behaviours like sexy comments, physical touches and physical attacks (Hiscox, 2018) are noted in routine at place of work. Even though this unwrap fact is painful to be absorbed, but until now it is the reflectiveness of the existing condition of occupied women in the planet. It is observed that incident of harassment taken place at in government and private offices, school, colleges, universities, factories or at any workplace.

Centre for Employment Equity (2018), reported that sexual harassment at workplaces has increased significantly during the last few decades and unfortunately the very few cases have been reported. According to available records by WHO facts sheet (2016), in every three women one experience physical or sexual harassment. There are so many factors that restrict women from taking action against culprits such as feeling of shame, fear of retaliation, losing the job and social pressure as well.

This unwanted and annoying sex-related behaviour (Fitzgerald et al., 1997) and concealing found within professional life and in almost every occupations. (Hunt, Davidson, Fielden \& Hoel, 2007). We cannot say that only weaker or low status women are victim of sexual harassment. If we look on the world scenario educated and socially strong women have been restricted for filing complains due to many unseen visible or invisible factors, they had to compel to remain silent even though they are being severly harassed sexually and psychologically. 
Political women are more powerful, strong and empowered as compared to other women, but they are still victimized to sexual harassment. Political institution is an important and reliable source of empowerment and the beauty of democracy within institution must be modelled at all level for every men and women. In political environment provide equal opportunity with totally freedom and security to men as well as women. In society, for the effectiveness of political institutions it is important to maintain gender equality. Unluckily, women are not saved in the strong political institution.

In 2016 and 2018, an Inter-parliamentary Union (IPU), published two global studies provided facts that harassment and violence with women is very common in political sphere in European countries, findings further disclosed that above 80 percent of women parliamentarian faced violence, threats of death, sexual harassment and psychological and physical violence including rape, beatings or abduction during their parliamentary tenure (IPU, 2016-2018).

All over the world the ground breaking movement ME-TOO and Time's up shattered the taboos and generated global attention regarding sexism and violence that women face in working atmospheres.

Politics is over whelming male-dominated according to world's fact Women politicians only 5.2 percent of heads of government, 6.6 percent chief of the State, and 24 per cent of the members of parliament all over the world. Women constantly challenge stereotype norms and traditions related to gender that have usually away from politics; they confront inappropriate and unfriendly attitude in these respectable institutions. Women are as in different places of work, gradually have found in political parties, government bodies, elected assemblies and in parliaments (Shaw, 2018).

Two years ago, in January 2017, the member of provincial assembly (MPA) Nusrat Sehar Abbasi constantly faced orally and psychologically harassment by their male fellow who were the member of house as well. She was victim of the gender base violence because harassed on the bases of sex not only by opposite party male members but also by her own party members. She also said that it is enough; I am sick and tired with the male legislators due to continuously hooting and used abusive language. Harassment and violence with women at the workplace especially for women politicians make more hard, dangerous and unattractive. In this situation mostly women do not join or adopt politics as a profession. It was not only one incident but on many occasion women politicians suffer unsuitable joking intentional to openly humiliate them on public gathering. In April 2017, a member of Pakistan People's Party Khurshid Shah said about women parliamentarian, if women prevented from gossiping, they would be sick. In June 2016, Khawaja Asif defence minister targeted physical appearance of 
another member of assembly Shireen Mazari 'tractor trolley and female supporters of PTI do not have good character, the head of JUI-F's Mulana Fazlur Rehman said in 2014. The worst thing was that the women legislators mostly failed to condemn this behaviour of male colleagues due to their party rules or fear of criticism by male.

In 2006, member of provincial assembly Shazia Marri also complained her male colleague Eshwar Lal had send immoral written massages. Few others women politicians including Marri complained of harassment by a MPA (Nadia, 2017). The nature of violence against women in politics can be mental, physical and sexual. Violence can be affected equally male and female but targeted to women is gender based in politics. Women targeted by their gender such as sexual harassment and violence, sexist remarks or jokes. In parliament and all political sphere sexual harassment and violence is a destruction of basic human rights. It is not only a violation of women political rights but also hold back women's political participation.

Harassment and violence in the workplace including political sphere is widespread in Pakistan but actual number of cases are not available, issue is still under the carpet. The fact that the majority of incidents are never reported, only few cases come into the front and highlighted. The data on the incidence of sexual harassment in the place of work do not collect by government and data on employment committees does not allow cases comprising charges of sexual harassment to be identified certainly.

\section{Objectives of the Study}

- To find out the political environment of women in political sphere

- To explore the categories of harassment faces by female political workers

- To find out the impact of harassment on the issues of political women lives

- To evaluate the challenges faced by women political workers at work place

- To know the attitudes of family towards the victim of sexual harassment

\section{Literature Review}

Review literature provides more information to a reader for understanding the research. It is observed that published material concentrate on the issue of women harassment with various points supported this exploration in bringing innovation to this research beside with understanding of present study. In Pakistani perspectives there is no research available that highlighted the issue of harassment and violence including physical \& sexual among political women. 
A number of studies (Berdahl, J. L. \& Moore, C., 2006; Barling, J., Rogers, A. G. \& Kelloway, E. K., 2001; Dekker, I., \&Barling, J., 1998; Fitzgerald, L. F., Shullman, S. L., Bailey, N., Richards, M., Swecker, J., Gold, Y., Ormerod, M. \& Weitzman, L., 1988; Schneider, et al 1997 ;Ellis, S., Barak, A. \& Pinto, A., 1991) supporting women harassment at the workplace as their focal theme, among them few researcher investigated emotional harassment on working women, some discovered its factors and approaches of prevention.

Arif et al., (2017) explored that the main contributors of stress are gender discrimination, peers' behaviour and sexual harassments as well among working women in Pakistan. Study further find out that along gazing and unnecessary conversation, the male colleagues discuss sexual matters, and loudly speak sexual jokes in the presence of women (Arif, A., Naveed, S. \& Aslam, R, 2017).

Maheen et al., (2016) held a study in management universities of Peshawar highlighted that sexual harassment does lead to worker turnover intentions and sexual harassment has increased in higher educational institute and HEC neither successful to remove this in academic societies nor proper execution the guidelines on SH (Maheen et al., 2016).

Researchers identified harassment among working women in media with insufficient reporting. Almost male offering pick and drop, invite lunch or dinner, touched while giving anything like papers, files or glass, unintentionally touched body, giving comments their appearance, praising their personality and offering voluntary services and some others also want to shake hand.Although media is considered modern, open mind people's institution (Zia, A., Batool, S. \& Yasin, Z., 2016).

Wherever women work, regardless of the profession incidents of harassment or sexual harassment occur at workplace (McLaughlin et al., 2012). Within all countries, including Pakistan (Naizi, 2012), many exploratory researches provide evidence that women faced sexual harassment. There are many factors and forces like existences of patriarchal deep rooted values in Asian region (Isran \& Isran, 2012, Richter 1991), particularly public patriarchy control and limited women's power (Heimer, 2000).

\section{Women's Political Participation}

In political participation of women, and their positions in government, the quantity of women's in power sharing comprises the number of females in administration and government (Robert, 2002; Peter, 1993). 
Unbiased and fair representation of women in political domain has an optimistic effect on gender mainstreaming in various policies and strategies. Worldwide, women's representation rose 24.1 percent in parliament at the end of 2018, 13 percent increased as compared to last twenty years.

Headships of women in the EU is above the world average in the beginning of 2019, four women presidents, two queens (UK \& Denmark) and three prime ministers among the 55 heads of the state and government in European countries. Globally, Rwanda has the impressive number of females' legislators; in the lower house women have succeeded 61.3 percent seats in parliament (European Union, 2019).

In each region, wide disparities continue exist in the average percentages of women parliamentarians, 42.3 per cent Nordic countries, 30 percent Americas, 27.7 percent Europe as well as Nordic countries,; 26.6 per cent, Europe without Nordic realms, 23.6 percent sub-Saharan Africa, 19.4 percent Asia, 17.8 percent Arab Countries and 17 percent the Pacific at the end of 2018 (IPU, 2018).

In Pakistan, the last Elections were held in 2018bring out 105 women throughout the country were given party tickets as compared to last election 74 female candidates contested on party tickets, while 66 competed without any political party candidate in 2018 as compared to 61 in 2013 (Salman, 2019).

Although gender norms and expectations significantly decrease the pool of women putting themselves forward for selection as candidates in election. Now a multidimensional approach requires for Women's empowerment in politics such as preventing sexual harassment / violence against women during elections. Additional determinations required to bring women into political parties and particularly young women, develop skills to participate actively in elections as candidates, voters and train to become a future leadership.

This is essential in the present political environment regard as citizens specially women disappointment with politics (European Union, 2019).According to the WEF, Pakistan's placed at 97 on political \& constitutional empowerment, only Bangladesh stretched outa level of gender uniformity of beyond $50 \mathrm{pc}$, while during this period India boast just about 40pc, in the Asian region (WEF, 2018).

\section{Sexual Harassment/Violence in Politics}

Through over the world sexual harassment and violence is an important, more common and disturbing human rights violation, irrespective of social upbringing, everywhere at home, at working place, at educational institute, in the pathway, playing game or more powerful places like political institutions. In the 2030 
Agenda for Sustainable Development, eliminating violence particularly against females and teenagers is an important goal. Even though the perception of sexual annoyance is along-standing subject (Thornton, 2002) and less discussed openly. It acknowledged as a societal occurrence in these days.

In politics violence against women is the result of long systematic structure of patriarchy. Many factors contribute to less representation of females in political affairs: hardly or even no one woman is the leadership of any political parties which is the first step for establishing the political leader in future. Violence in every form is not enclosed to politics on the other hand to the wide-ranging in general places, wherever the dynamic of power will change the traditional political structure and will transport to the forefront different supremacy, energetic and cognitive structures of females in the public domain.

The raising of the \#MeToo movement provide more courage to more women, media and political women speak out and reported harassment and sexist remarks (IPU, 2018).

Celebrated moment for the women of United States in political sphere the midterm elections 2018, when the extraordinary number of women entered and designated to legislative body. This outstanding accomplishment was not an easy flight but steadily and a hard struggle. Along with enlargement of women's parliamentary partnership the result of a distressing increase in cyber bullying of these identical women and their political rights under threats. Particularly women who are serving in different prominent roles as stateswomen and leaders have been targeted through cyber harassment.

Amnesty international surveyed 4000 female workers within eight independent, self-ruled, economically top ranking countries, as well as the United States in 2017, to explore that almost 76out of each hundreds of those women had faced different categories of sexual exploitation on social networking. The cyber molestation includes physical appearance, sexual orientation, using their snapshots to give the impression in vulgar prospects. Harassment is creating hurdles for blocking women from exercising their political rights and participates in politics (Centre for strategic and International Studies, 2018).

A research conducted by ComRes for the BBC in November 2017, interviewed 6,206 mature adult person in Britain, pointed out fourteen percent of interviewers had suffered from sexual intimidation in the workplace. It was consisted on demonstrations of indecent images, unwanted remarks vulgar funny stories or jokes related to sensual nature (BBC, 2016-2017). Another research study explored that more than $50 \%$ of women engaged in wage labour in European Union countries which has experienced sexual harassment. Study further explored 
that in the workplace discrimination and inequalities can be mused a cause of sexually abuse or harassment, through evidence collected in the research and further described association between sexual abuse and inequalities within male and female (The House of Commons, 2017-19, p.7).

The IPU conducted a study in European countries in 2016, 123 women from 45 European countries consisted 81 parliamentarian and 42 parliamentary staff. The research explored $40.5 \%$ respondents harassed sexually in their duties, the perpetrators were male MPs in 69.2 percent of cases, $50 \%$ had eavesdrop sexy remarks and $61.5 \%$ of these cases the perpetrators were male MPs, $19.5 \%$ of respondents faced psychological harassment from their colleges MPs. Further findings give alarming facts the reporting are these cases very low. Only $23.5 \%$ of MPs and 6\% female parliamentary staff had reported the incident who had been sexually harassed. Study findings showed that more women parliamentarian go under report while facing sexual harassment still underreported (IPU, 2016).

\section{Legal Framework and Definitions}

In politics, sexual harassment and violence against women are flagrant and intolerable violations of fundamental and political rights, including the obligation to ensure that women can participate fully, freely and safely in political processes including in parliaments. Several international instruments protect these rights, such as the Convention on the Elimination of All Forms of Discrimination against Women (CEDAW), the International Covenant on Civil and Political Rights and the Sustainable Development Goals (SDGs).

In politics, the issue of harassment and abuse with women increased gradually at international level day by day, even that matter discussed its causes and consequences that matter talk over at the General Assembly of United Nations in 2018.

The Article 2 of UN Declaration on Violence against Women explain in detail about sexual harassment and coercion at workstation, Pakistan is a signatory of this declaration, moreover, Pakistan is also joined to the International Labour Organisation Convention 100 and 111deals with equal wages for equal value of work and discrimination in employment.

Any type of non-consensual sexual violence prohibited by state law, comprehend the victim do not giving the position of consent, define by the U.S. Department of Justice, (OVW).

The U.S. Equal Employment Opportunities Commission (EEOC) states that "undesirable spoken, photographic, nonverbal, or physically conduct that is the 
nature of sexual or derived on someone's sex, constitutes sexual harassment. Precedent has established for legal step, at place of working harassment should be "brutal or prevalent" and disturb operational or working environment (HISCOX, 2018).

In Asian countries proof towards harassment at place of work are not recorded appropriate however more or less within all countries in the region sexual harassment is being practiced. The Philippines passed an Anti-Sexual Harassment Act in 1995, which support not to were established accept harassment at the workplace. In Thailand, include punishments for sexual violations at place of employment through amendment in its labour laws in 1998. Similarly in Asian nations approved numerous bills to be responsible for protected, in offensive and harmless atmosphere for female like Malaysia and Pakistan as well.

Pakistan national assembly passed The Protection against Harassment of Women at Workplace Act 2010, protecting the female employ from sexually irritation at workroom. The act harassment is clarified as, "any undesirable sensual advance, demand for sexually exceptional behaviour, verbal or on paper communication, physical relation or sexually demeaning assertiveness, produce intervention with performance of work.

\section{Methodology}

There is no other study is available about harassment among political workers so present study is an exploratory and descriptive. In this study, the methodology adopted was quantitative and involved semi-structured questionnaire which consisted open ended and close ended questions.

Major objective of the study to find out the contemporary status of persecution in Pakistani political workers in Karachi, researcher had used survey method with purposive and snow ball sampling procedures, picking prospective respondents for getting appropriate data to achieve the aims of the present research. Both sampling are under non-probability method, purposive sampling provides help to select the sample on the bases of characteristics, while snowball method gives information to find out other participants and easy for researcher to catch the relevant person within short time.

The data was collected through interview schedule from 200 literate, unmarried and married women. The interviewed women were 15 to 40 years old, who work as a political worker in different political parties. Respondents affiliated Pakistan people's party, Pakistan Tehrek-e-Insaaf, Mutehda Qumi Movement and Pakistan Muslim league (N). 
The interviews were conducted face to face at their homes. Respondents were asked how they were physical and mentally sexually harassed and exploited during their work in offices, outsides, election campaigns, political gatherings and in the cabinets. The collected data has been tabulated and analysed. In the present study, simple distribution frequency tables, frequency and percentages was used to represent research findings, first of all, simple tables were made representing each question and percentages were drawn.

\section{Findings \& Discussion}

Gender discrimination, violence against women, sexual harassment and sexual violence exclusively observed during work remained uncontrolled which is considered common violation of women rights. Sexual harassment at workplace is a social humiliation and promote unhealthy environment especially for women, although women participation in the work force is increasing day by day. It is appalling that undesirable sexual conducts like sexual remarks, gazing, touching, stalking, sending vulgar text messages, openly conversation on sexual issues in front of women and physical attacks are observed in the workplace even these type of incidents are looked around day to day prevalence and part of ethos in place of work.

Gender inequalities are very common in developing countries including our beloved country Pakistan. Women are considered inferior, less than second citizen and mostly least important in decision making process regardless within home or working place. Mostly women face violence due to gender inequality; it is corelate different kinds of discriminations related to workplace and sexual harassment as well.

Politics is also perceived as a restricted area of working for girls and mostly parents do not allow their daughters to participate in political activities like meetings, protest, corner meetings and public gatherings. But now consequence has going to be changed and present study find out that $77.5 \%$ respondents have had family support to join politics as compare to only $22.5 \%$ respondents' family did not support them. Data indicated a big change in our social system, few years ago politics is not considered for women working area. As since long political sphere influenced by masculine, universally it's all about for male control and command too. On the other hand women's contribution and participation in political domain do not see as pleasing as appraised like present epoch. (See table 2 ) if women have to reach in assemblies then they will play their vital role for women empowerment through positive and women's friendly legislation. Participants were asked about their perceptions to join politics, primary data shows that $56.5 \%$ respondents join politics to their self-desire, $23.5 \%$ respondents 
entered in politics for getting power, while $15 \%$ already from political families (see table .1).

Workplace for a political worker is very wide-ranging such as office, rallies, and public meetings, demonstrations etc. in the workplace categorizing occupational elements associated and increased possibility of sensual irritation and physical attacks. The study focused on female political party workers who are affected by gender based violence and data shows women in our society regardless they are house workers or working lady. They all feel suppress as a women, they all harass being a women. Above table shows that $58 \%$ of respondents feel suppress as a women worker in their own political party. Only $42 \%$ respondents did not feel any inferiority or pressure. Women in our society regardless they are house workers or working lady, they all feel suppress as a women, they all harass being a women. The results of the study shows that $44.6 \%$ respondents had faced sexual harassment during election campaign, $24.4 \%$ respondents harassed in the office sphere, and $21.2 \%$ respondents had faced harassment during different demonstrations about $50.5 \%$ respondents harassed verbally and $49.5 \%$ harassed by physically or nonverbal (See table. 3 ).

Harassment exists in different types which women faces at workplace. Most common shared by the respondents are gazing, laughing, Sexual jokes and comments, touching, pushing, unwanted jokes and dialogues, holding hand, indecent body language, negative messages on mobile or different type of social media, offering pick and drop, gifts and use indecent language. Harassment has two main categories verbal and non-verbal. The result of this study explored in the case of verbal harassment $58.4 \%$ respondents harassed by gazing and laughing, 16.8\% respondents received vulgar text messages and calls with abusive or sexual language, $12.8 \%$ respondents harassed by sexual jokes and $11.8 \%$ respondents had been the subject of a remark of sexual nature. The facts about non-verbal harassment $61.6 \%$ respondents said they suffered senseless incidents like push and it is very easy to prove these types of thrust as unintentional touch, $22.2 \%$ respondents faced unwanted touches with fingers, elbow or legs etc., $12.1 \%$ respondents suffered due to stalking, 3.1\% percent respondents had been faced physical violence with sexual harassment while only one respondent told she has been subjected to sexual violence (SeeTable.4).

Mostly women faced sexual harassment by their boss or seniors and it is very common at places of work, situation is worst when the ladies staff employed are lesser than male staff, newly appointed and low social status. In the present research fact shows that a large number of female political workers sexually harassed by their colleagues $(62.5 \%)$ and $(18.6 \%)$ head. (See Table .5)Because this is the game of power, who has in power will use and who is in the 
subordinate position or weaker will bear this burden. Our culture and traditions restricted to women due to their modesty and religious piousness.

Social stress is also the reason of silence, women do not have to right to claim or raise voice even they cannot discuss on sexual harassment openly around $40.6 \%$ respondents just share with their friends, $34.4 \%$ respondents complained to higher authority, only $25 \%$ respondents told their family while not a single person complained to police or did not take any legal action. Mostly women do not make a voice against sexual harassment at workplace either they strong or weak, literate or illiterate, older or younger, belong elite class or middle class, it does not make any difference among them. a survey report by DAWN evident that, 300 women were interviewed across professions and industries about workplace harassment, according to fact 35 percent were remain silent by their colleagues and bosses while 17 percent women approached their organisation's internal inquiry committees (Table.6).

There is an important fact that by bearing this burden woman cannot share and hide this crime; social pressure and burden of insecurity are destroying the reputation of women (Human Rights Watch, 2018). The offender gets benefit to their position and status, male dominated society criticize, blame and discuss on women's character. Due to mentioned reasons women do not want to disclose or complained about sexual harassment or violence.

The facts of study showed that $21.6 \%$ respondents did not have courage to complain due to their reputation, $33.3 \%$ respondents did not inform due to fear of family, 35.2\% respondents did not get attenuation on male behaviour, had not complained or informed to anyone just ignored. (See Table 6)Majority of the female workers evade sharing their painful feelings or talk over these sorts of problems to others, even though they do not share to the head and authority person. It is observed that women have such as their own fear, societal pressure, persons influence, and fear of insult, fear of threats (self-fear \& family), embarrassment, lack of confidence and lack of proper support system.

Due to above said reasons women do not courage for reporting, ignored and decided to keep silent. But the silence of women encourages the delinquent to carry on the criminal and insulting behaviour (Hoffman, Hamlin, 2002). Shazia Marri has complied about her male MPA Eshwer Lal that he had been harassed her for two years. But when she had take action and registered legal complaint against him then he stopped. But that is another fact when women report the issue they face victimization from society. Aisha Gulali and Meenashafi are more example of this situation, both women are faced more discrimination and social pressure when the rose their voice against male's attitude or sexual harassment. 
Major concentration of this research had to investigate standing condition of abuse and harassment in women political workers. Environment of any political office and outside essentially controlled these types of incidents because unsafe working environment effected the creativity and productivity of any person particularly women, who developed their political skills and practicing for future leadership. Workplace environment plays an important role for building personality traits gender based insult at workplace has been extremely linked with atmosphere of the place of work. Gender imbalance in any occupation or work place has increased the risk of harassment at workplace. According to Hunt gender composition is very important for occupation or workplace (Hunt, 2007).

Since long in society masculine controlled life have exaggerated social and cultural structure, and women considered sub servant or in a secondary position (Hong, 2003). The reality of harassment is that almost majority of men are involved in heinous action at workplace (Malamuth, \& Briere, 1986).

An interviewed political worker argued that the quantity of women have increased in politics but until now dominated by male. Women do not consider for higher positions or key post as compared to male, they are more reliable and deserve for part tickets and election while women political workers are consider only a tool for using as a female.

Keeping the main purpose of the research about occurrence of gender biased attitudes in political women workers, questioned from women who affiliated with any political party to achieve objectives of this exploration and receiving facts show intact women faced sexual abuse at their workstation, field work, during rallies, protest and political public and private gatherings.

Sexual harassment at workplace and particularly in political atmosphere itself is curse but it is more painful when politicians who make rules, laws and they do not apply within their own parties, their own parliamentarians and political workers has not saved to this heinous crime.

The government has unsuccessful to progress and enlarge financial and political privileges proposed for feminine, even though so many amendments including new laws in the constitution of Pakistan. The government is not only failed to implantation of laws and also restrict to put on to protect existing laws (Akhtar \& Métraux, 2013; Nosheen, 2011; Qureshi, 2013). It is a bitter truth that, the law enforcement bodies, such as police (table, 10) itself is a threat for the safety of women, and the harassment or victimization from police are common practice in our society (Abbas, 2011). 


\section{Conclusions}

The present study explored sexual harassment among women political workers. The situation is no more different from other professions and outcomes of this research show that women are suffering from harassment in political sphere. For this study researcher interviewed 200 women political workers. All respondents agreed that political workers are being harassed at their workplace. Female participation is increasing gradually in political domain. Many interviewers shared that number of cases are increased but reporting is decreased due to many factors behind this phenomenon. The results of the research showed that female workers faced different kind of harassment like touching, comments on their physical appearance, sexual jokes etc. while staring is the very common and do not count in harassment, almost women do not share or inform others about sexual violence. There is need to immediate address to sexual harassment because if any woman harassed in the world of work is worst but there are a number of women affected with sexual harassment.

\section{References}

Abbas, H. (2011). Reforming Pakistan's Police and Law Enforcement Infrastructure. US Institute of Peace, Washington, DC.

Akhtar, N. \& Métraux, D. A. (2013). Pakistan is a Dangerous and Insecure Place for Women. International Journal of World Peace, vol.30:2, pp.35-70.

Ahsen, Saud (February 13, 2019). Workplace Harassment Law in Pakistan, Daily Times, Karachi, Pakistan. Retrieved from: https://dailytimes.com.pk/ 353990/workplace-harassment-law-in-pakistan/

Arif, A., Naveed, S. \& Aslam, R. (2017). Factors Causing Stress among Pakistani Working Women. Pakistan Administrative Review, vol.1:3, pp.159-174.

Barling, J., Rogers, A. G. \& Kelloway, E. K. (2001). Behind Closed Doors: InHome Workers' Experience of Sexual Harassment and Workplace Violence. Journal of Occupational Health Psychology, vol.6:3, pp.255269.

BBC - Sexual harassment in the work place (2017). Survey by ComRes, November 2017; BBC Radio 5 Live - Sexual harassment in the workplace 2017, survey by ComRes, October 2017; TUC, Still just a bit of banter? Sexual harassment in the workplace in 2016, August 2016 
Berdahl, J. L. \& Moore, C. (2006). Workplace Harassment: Double Jeopardy for Minority Women. Journal of Applied Psychology, vol.91:2, pp.426-436.

CEDAW, General Comment on Art. 11 of General Recommendation No. 19 (11th Session, 1992).

Centre for Strategic and International Studies, (2018) Against The Odds: Overcoming Online Harassment of Women in Politics, CSIS, Washington, USA retrieved from: https://www.csis.org/analysis/against-oddsovercoming-online-harassment-women-politics

Dekker, I. \& Barling, J. (1998). Personal and Organizational Predictors of Workplace Sexual Harassment of Women by Men. Journal of Occupational Health Psychology, vol.3:1, pp.7-18.

Ellis, S., Barak, A. \& Pinto, A. (1991). Moderating Effects of Personal Cognitions on Experienced and Perceived Sexual Harassment of Women at the Workplace. Journal of Applied Social Psychology, vol.21:16, pp.1320-1337.

European Union, (2019). Women in Politics: A Global Perspective, EPRS | European Parliamentary Research Service.

Fitzgerald, L. F., Shullman, S. L., Bailey, N., Richards, M., Swecker, J., Gold, Y., Ormerod, M. \& Weitzman, L. (1988). The Incidence and Dimensions of Sexual Harassment in Academia and the Workplace. Journal of Vocational Behavior, vol.32:2, pp.152-175.

Fitzgerald, Orasgow, Hulin, Gelf \& Magley, (1997) Antecedents and Consequences of Sexual Harassment in Organizations: A Test of an Integrated Model, Journal of Applied Psychology, vol.82:4, pp.578-589.

Farid, N., Abbasi, S., Ali, R. \& Ashfaq, A. (2016). Experiences of Women Police at Work Place in Pakistan. Pakistan Journal of Criminology, vol.8:3, pp.149-162.

Hamlin, L. \& Hoffman, A. (2002). Perioperative Nurses and Sexual Harassment. AORN J, vol.76, p.855-860.

Heimer, K. (2000). The Nature of Crime: Continuity and Change. Changes in the Gender Gap in Crime and Women's Economic Marginalization. Criminal Justice, vol.1, pp.427-483. 
Hiscox, (2018). Work Place Harassment Study, Hiscox, London. p.3. Retrieved from: https://www.hiscox.com/documents/2018-Hiscox-Workplace-HarassmentStudy.pdf

Hong, Z. R., Veach, P. M. \& Lawrenz, F. (2003). An Investigation of the Gender Stereotyped Thinking of Taiwanese Secondary School Boys and Girls. Sex Roles, vol.48:11, pp.496-503. Retrieved from: http://www.springerlink.com/ content/k776310631124817/fulltext.pdf

Human Rights Watch (2018). Ending Violence and Harassment at Work: The Case for Global Standards, p.10, https:/www.hrw.org/sites/default/files/news_ attachments/2018_hrw_ilo_brochure.pdf

Hunt, C., Davidson, M., Fielden, S. \&Hoel, H. (2007). Sexual Harassment in the Workplace: A Literature Review (Working Paper Series No. 59), pp. 20, 29, 66. University of Manchester, Arndale Centre. Retrieved from: http://research.mbs.ac.uk/equalitydiversity/Portals/0/docs/WPS59Sexualha rassment.pdf

Hunt, C., Davidson, M., Fielden, S. \& Hoel, H. (2007). Sexual Harassment in the Workplace: A Literature Review. Manchester Business School, University of Manchester.

HRPA, (2018). Doing Our Duty: Preventing Sexual Harassment in the Work Place, Human Resource Professional Association, USA p.7.

Inter-Parliamentary Union (IPU) and Parliamentary Assembly of the Council of Europe (PACE), (2018). Sexism, Harassment and Violence against Women in Parliaments in Europe, Geneva.

ILO. Ending Violence and Harassment against Women and Men in the World of Work, Report V(1) (2018), International Labour Organization, Geneva.

Isran, S. \& Isran. A.M. (2012). Patriarchy and Women in Pakistan: A Critical Analysis, Interdisciplinary Journal of Contemporary Research in Business, vol.4:6, pp.835-859.

Maheen et al., (2016). Sexual Harassment at Workplace and its Impact on Employee Turnover Intentions, Business \& Economic Review, vol.8:1, pp.87-102. 
McLaughlin, Heather, Christopher Uggen \& Amy Blackstone (2017). The Economic and Career Effects of Sexual Harassment on Working Women. Gender \& Society, vol.31:3, pp.333-58. https://doi.org/10.1177/0891243217704631.

Mc, Cann, Donald T., Kovic, \& Badgett, (2018). Employer's Responses to Sexual Harassment, Center for Employment Equity, USA retrieved from: https://www.umass.edu/employmentequity/about-center-employmentequity

Malamuth, N. M. \& Briere, J. (1986). Sexual Violence in the Media: Indirect Effects on Aggression against Women. Journal of Social Issues, vol.42:3, pp.75-87.

Nadia Jajja (Sep 18, 2017). Women and Sexual Harassment at the Workplace, HERALD, The Dawn Group of Newspapers, Karachi, Pakistan.

Niazi, A. (2012). Expressions of Modernity in Rural Pakistan: Searching for Emic Perspectives. Oregon State University.

Nosheen, H. (2011). Violence against Women. Dialogue, vol.6:3, pp.290-299.

Peter, M.W. \& Susanne, F. (1993). Public Participation in Waste Management Decision Making: Analysis and Management of Conflicts, Journal of Hazardous Materials, vol.33, pp.355-368.

Qureshi, S. (2013). The Emergence/Extension of Due Diligence Standard to Assess the State Response towards Violence against Women/Domestic Violence. South Asian Studies, vol.28:1, pp.55-66.

Robert, A.D. \& Bruce, S. (2002). Modern Political Analysis, Upper Saddle River: Prentice Hall.

Richter, L.K. (1991). Explaining Theories of Female Leadership in South and South East Asia, Pacific Affairs, vol.63, pp.524-540.

Salman, Ali (June 02, 2019). The Political Participation of Women, Daily Times, Karachi, Pakistan.

Sadruddin, M. M. (2013). Sexual Harassment at Workplace in Pakistan-Issues and Remedies about the Global Issue at Managerial Sector. Journal of Managerial Sciences, vol.3:1, pp.1-114. 
Schneider, K. T., Swan, S. \& Fitzgerald, L. F. (1997). Job-Related and Psychological Effects of Sexual Harassment in the Workplace: Empirical Evidence from Two Organizations. Journal of Applied Psychology, vol.82:3, pp.401-415.

Shaw, E., Ariane, H, \& Cynthia, H. (2018). Sexual Harassment and Assault at Work: Understanding the Costs (briefing paper), Institute for Women Policy Research (IWPR), Washington, DC 20036 USA.

The Global Gender Gap Report (2018). World Economic Forum (WEF), Switzerland, p.215.

The House of Commons: Women and Equalities Committee, Sexual Harassment in the Workplace, Fifth Report of Session 2017-19, p.7, retrieved from: https://www.parliment-uk/.../committees/committees.../commons....womenand-equality

Thornton, M. (2002). Sexual Harassment Losing Sight of Sex Discrimination. Melbourne University Law Review, vol.26:2, pp.422-444.

McLaughlin, H., Uggen, C. \& Blackstone, A. (2012). Sexual Harassment, Workplace Authority, and the Paradox of Power. American Sociological Review, vol.77:4, pp.625-647.

Sharma, Preeti (2014). Oligarchic Patriarchal Political Culture of Women Participation in South Asia: With Special Reference to India, Bangladesh, Pakistan. The Research Paper to be Presented in the World Congress 2014 Organized by IPSA from 19th- 24th July 2014 at Montreal, CANADA Retrieved from: https://pdfs.semanticscholar.org/a9a6/01bafdd6c423ed 528744751a6bf3d432aefe.pdf

U.S. Department of Justice, Office on Violence Against Women. 2018. "Sexual Assault." Retrieved from: https://iwpr.org/publications/sexual-harassmentwork-cost/

World Health Organization (WHO). (2016). Violence Against Women: Intimate Partner and Sexual Violence Against Women. WHO

Zia, A., Batool, S. \& Yasin, Z. (2016). Women Harassment at Workplace: A Study of Pakistani Television Channels. Global Media Journal: Pakistan Edition, vol.9:1, p.5. 
Annex

Table: 1

Distribution of respondents according to why you join politics

\begin{tabular}{|l|l|l|}
\hline Why you join politics & Frequency & percentage \\
\hline For Get power & 47 & $23.5 \%$ \\
\hline Self-desire & 113 & $56.5 \%$ \\
\hline Political Backgrounds & 30 & $15 \%$ \\
\hline Friends Motivate & 10 & $5 \%$ \\
\hline Total & 200 & $100 \%$ \\
\hline
\end{tabular}

Table: 2

Distribution of respondents according to did your family support you to join politics

\begin{tabular}{|l|l|l|}
\hline Your family support you to join politics & Frequency & Percentage \\
\hline Yes & 155 & $77.5 \%$ \\
\hline No & 45 & $22.5 \%$ \\
\hline Total & 200 & $100 \%$ \\
\hline
\end{tabular}

Table: 3

Distribution of respondents according to they feel suppress as a women worker in political party

\begin{tabular}{|l|c|c|}
\hline Feel suppress as a women worker in political party & Frequency & Percentage \\
\hline Yes & 116 & $58 \%$ \\
\hline No & 84 & $42 \%$ \\
\hline Total & 200 & $100 \%$ \\
\hline If yes then where & Frequency & percentage \\
\hline In the office & 9 & $24.4 \%$ \\
\hline During outside work & 23 & $9.5 \%$ \\
\hline During demonstration & 20 & $21.2 \%$ \\
\hline During election campaign & 42 & $44.6 \%$ \\
\hline Total & 94 & $100 \%$ \\
\hline
\end{tabular}

Table: 4

Distribution of respondents according to face harassment during work

\begin{tabular}{|l|l|l|}
\hline Face harassment during work & Frequency & Percentage \\
\hline Verbal & 101 & $50.5 \%$ \\
\hline Non verbal & 99 & $49.5 \%$ \\
\hline Total & 200 & 100 \\
\hline Verbal nature of harassment & & \\
\hline Sexual comments & 12 & $11.8 \%$ \\
\hline Sexual jokes & 13 & $12.8 \%$ \\
\hline Gazing \& laughing & 59 & $58.4 \%$ \\
\hline Text messages \& call & 17 & $16.8 \%$ \\
\hline Total & 101 & $100 \%$ \\
\hline
\end{tabular}




\begin{tabular}{|l|l|l|}
\hline Non-verbal harassment & & \\
\hline Touch & 22 & 22.2 \\
\hline Push & 61 & 61.6 \\
\hline Holding hand & 3 & $03.1 \%$ \\
\hline Stalking & 12 & $12.1 \%$ \\
\hline Sexual violence & 1 & $01.1 \%$ \\
\hline Total & 99 & $100 \%$ \\
\hline
\end{tabular}

Table: 5

Distribution of respondents according to who harassed

\begin{tabular}{|l|l|l|}
\hline Who harassed & Frequency & Percentage \\
\hline Colleagues & 125 & $62.5 \%$ \\
\hline In charge & 37 & $18.6 \%$ \\
\hline Police & 17 & $8.5 \%$ \\
\hline Public & 29 & $14.5 \%$ \\
\hline Total & 200 & $100 \%$ \\
\hline
\end{tabular}

Table: 6

Distribution of respondents according to did they inform or complain

\begin{tabular}{|l|l|l|}
\hline Inform or complained & Frequency & percentage \\
\hline Yes & 89 & $44.5 \%$ \\
\hline No & 111 & $55.5 \%$ \\
\hline Total & 200 & $100 \%$ \\
\hline if yes then whom & & \\
\hline Family & 82 & $25 \%$ \\
\hline Police & 0 & $0 \%$ \\
\hline Superior/ Authority person & 22 & $34.4 \%$ \\
\hline Friend & 76 & $40.6 \%$ \\
\hline Total & 89 & $100 \%$ \\
\hline \hline if not then why & & \\
\hline Ignored & 39 & $35.2 \%$ \\
\hline influence person & 11 & $9.9 \%$ \\
\hline Reputation & 24 & $21.6 \%$ \\
\hline fear of family & 37 & $33.3 \%$ \\
\hline Total & 111 & $100 \%$ \\
\hline & & \\
\hline
\end{tabular}

Dr. Aliyah Ali is an Assistant Professor in the Centre of Excellence for Women's Studies, University of Karachi.

Rukhsana is Visiting Faculty in the Centre of Excellence for Women's Studies, University of Karachi. 